Tetranucleotide repeat polymorphism at the human c-fes/fps proto-oncogene (FES)

Mihael H.Polymeropoulos, Denise S.Rath, Hong Xiao and Carl R.Merril

National Institute of Mental Health Neuroscience Center, St. Elizabeths Hospital, Room 131, 2700 Martin Luther King Avenue, Washington, DC 20032, USA

Source/Description: The polymorphic (ATTT) $)_{\mathrm{n}}$ repeat begins at base pair 4713 in intron $V$ of the human $c-f e s / f p s$ proto-oncogene on chromosome $15 q 25$-qter (1). The polymorphism can be typed using the polymerase chain reaction (PCR) as described previously (2). The predicted length of the amplified sequence was $154 \mathrm{bp}$.

Primer sequences:

GGAAGATGGAGTGGCTGTTA (ATTT strand); CTCCAGCCTGGCGAAAGAAT (TAAA strand).

Frequency: Estimated from 48 chromosomes of unrelated individuals.

Heterozygosity Index: $=75 \%$. PIC $=0.70$.

$\begin{array}{llll}\text { Allele (bp) } & \text { Frequency } & \text { Allele (bp) } & \text { Frequency } \\ \text { C1 } 163 & 0.04 & \text { C4 } 151 & 0.27 \\ \text { C2 } 159 & 0.23 & \text { C5 } 147 & 0.02 \\ \text { C3 } 155 & 0.33 & \text { C6 } 143 & 0.11\end{array}$

Mendelian Inheritance: Co-dominant segregation was observed in two informative families.

Chromosomal Localization: The human c-fes/fps proto-oncogene has been assigned to chromosome 15q25-qter (3).

Other Comments: The PCR reaction was performed on $80 \mathrm{ng}$ of genomic DNA using 100 pmoles of each oligonucleotide primer. The samples were processed as described (4) except that the denaturation cycle at $94^{\circ} \mathrm{C}$ was extended to 1.4 minutes. The tetranucleotide repeat was based on a (ATTT) 11 sequence.

References: 1) Roebroek,A.J.M. et al. (1985) EMBO J. 4, 2897-2903. 2) Weber,J.L. and May,P.E. (1989) Am. J. Hum. Genet. 44, 388-396. 3) Harper,M.E. et al. (1983) Nature 304, 169-171. 4) Weber,J.L. et al. (1990) Nucl. Acids Res. 18, 4637.

\section{Dinucleotide repeat polymorphism at the human CTLA4 gene}

Mihael H.Polymeropoulos, Hong Xiao, Denise S.Rath and Carl R.Merril

National Institute of Mental Health Neuroscience Center, St. Elizabeths Hospital, Room 131, 2700 Martin Luther King Avenue, Washington, DC 20032, USA

Source/Description: The polymorphic $(\mathrm{AT})_{\mathrm{n}}$ repeat begins at base pair 642 of exon 3 of the human CTLA4 gene (1). The polymorphism can be typed using the polymerase chain reaction (PCR) as described previously (2). The predicted length of the amplified sequence was $128 \mathrm{bp}$.

Primer sequences:

GCCAGTGATGCTAAAGGTTG (AT strand); AACATACGTGGCTCTATGCA (TA strand).

Frequency: Estimated from 38 chromosomes of unrelated individuals.

Heterozygosity Index $=92 \%$. PIC $=0.91$.

$\begin{array}{llll}\text { Allele (bp) } & \text { Frequency } & \text { Allele (bp) } & \text { Frequency } \\ 130 & 0.03 & 106 & 0.03 \\ 128 & 0.03 & 104 & 0.13 \\ 124 & 0.03 & 102 & 0.10 \\ 122 & 0.13 & 100 & 0.08 \\ 120 & 0.03 & 98 & 0.03 \\ 118 & 0.08 & 96 & 0.05 \\ 112 & 0.05 & 94 & 0.03 \\ 110 & 0.10 & 92 & 0.05 \\ 108 & 0.03 & & \end{array}$

108

0.03

Mendelian Inheritance: Co-dominant segregation was observed in two informative families.

Chromosomal Localization: CTLA4 has been assigned to chromosome 2q33 (1).

Other Comments: The PCR reaction was performed on $80 \mathrm{ng}$ of genomic DNA using 100 pmoles of each oligonucleotide primer. The samples were processed as described (3) except that the denaturation cycle at $94^{\circ} \mathrm{C}$ was extended to 1.4 minutes. The dinucleotide repeat was based on a $(\mathrm{AT})_{28}$ sequence.

References: 1) Dariavach,P. et al. (1988) Eur. J. Immunol. 18, 1901 - 1905. 2) Weber,J.L. and May,P.E. (1989) Am. J. Hum. Genet. 44, 388-396. 3) Weber,J.L. et al. (1990) Nucl. Acids Res. 18, 4637. 